\title{
RELIGIÓN O SUPERSTICIÓN. UN DEBATE ILUSTRADO EN LA ESPAÑA DEL SIGLO XVIII
}

\author{
POR \\ FERNANDO MARTÍNEZ GIL \\ Universidad de Castilla-La Mancha \\ Fernando.Martinez@uclm.es
}

\section{RESUMEN}

El término superstición es un concepto histórico y, como tal, ha ido variando a lo largo de los siglos y de las culturas. Entendido siempre en relación a la idea de religión, fue definido como una religión falsa o impropia, y otras veces como el extremo opuesto de la impiedad, pasando la religión a ocupar el centro o ideal de virtud. Si el debate sobre la religión jugó un papel decisivo en la configuración de un pensamiento ilustrado propiamente español, también lo tuvo, en consecuencia, el debate sobre la superstición. El presente trabajo profundiza en ese debate crucial que consumó el desencuentro entre la cultura oficial y la cultura o culturas populares.

PALABRAS CLAVE: Religión, Superstición, Ilustración, Cultura popular.

\section{RELIGION OR SUPERSTITION: AN ENLIGHTENED DEBATE IN SPAIN OF THE EIGHTEENTH CENTURY}

\begin{abstract}
The term "superstition" is a historical concept and, as such, it has changed throughout centuries and cultures. Always understood in relation to the idea of religion, it was defined as a fake or inappropriate religion, and in other occasions as the opposite end to impiety, while religion was relocated in the middle or ideal of virtue. Therefore, not only the discussion about religion, but also about superstition played a decisive role in the shaping of the particular Spanish way of thinking during the Enlightenment. The present work deals in depth with this crucial debate that culminated in the disagreement between official culture and popular culture or cultures.
\end{abstract}

KEY WORDS: Religion, Superstition, Enlightenment, Folk Culture.

$\begin{array}{ll}\text { Recibido/Received } & \text { 02-04-2012 } \\ \text { Aceptado/Accepted } & 15-12-2015\end{array}$

\section{SUPERSTITIO}

La frontera entre religión y superstición ha sido históricamente -y aún lo es- muy tenue y movediza. Si, en términos antropológicos "no existe definición universal de la religión",1 el concepto de "superstición" no puede ser más equívoco. En el diccionario de María Moliner se define como toda "creencia en alguna influencia no explicable por la razón en las cosas del mundo", ${ }^{2}$ lo que situaría a la reli-

1 Hunter, D.E. y Whitten, Ph. 1981. Enciclopedia de Antropología: 564. Barcelona: Ed. Bellaterra. "El alcance y naturaleza de los estereotipos históricos, de amplia variedad cultural y demás fenómenos en ella involucrados son muy discutidos y producen interpretaciones extraordinariamente contradictorias".

2 Moliner, M. 2007, Diccionario de uso del español: t. II, 2791. Madrid: Gredos. También en la Gran Enciclopedia Larousse, t. 22, 10.488: gión, o religiones, dentro de su ámbito. Otros diccionarios, algo más confesionales, optan por una definición bastante menos radical, como el de la RAE, que entiende por superstición la "creencia extraña a la fe religiosa y contraria a la razón", como si fe y razón fuesen una misma cosa. ${ }^{3}$ Desde una mentalidad de reconocida religiosidad no es raro que se tilden de supersticiosas las demás religiones, falsas en relación a la única verdadera. Ya escribió Voltaire en pleno siglo ilustrado que "los musulmanes acusan de este defecto a todas las sociedades cristianas, y éstas los acusan a ellos"; pero, aún dentro del cristianismo, "no están acordes las

\footnotetext{
"Tendencia, derivada del temor o de la ignorancia, a atribuir carácter sobrenatural sagrado u oculto a determinados acontecimientos".

3 Diccionario de la lengua española de la Real Academia de la Lengua.
} 
sociedades cristianas en lo que es la superstición" y "hoy la mitad de Europa cree que la otra mitad fue durante mucho tiempo supersticiosa, y lo es todavía". Y concluye:

"Es difícil marcar los límites de la superstición. El francés que viaja por Italia encuentra allí mucha superstición, y no se equivoca. El arzobispo de Canterbury opina que el arzobispo de París es supersticioso; los presbiterianos dicen que tiene ese defecto el obispo de Canterbury, y los tratan de supersticiosos los cuáqueros, que es la secta más supersticiosa para los demás cristianos". ${ }^{4}$

Habría también una superstición interna en el seno de cada religión, como se deduce del comentario del mismo Voltaire:

"Los protestantes consideran las reliquias, las indulgencias, las maceraciones, rezar por los muertos, el agua bendita y casi todos los ritos de la Iglesia romana como locuras supersticiosas. Según ellos, la superstición consiste en creer que esas prácticas inútiles son prácticas necesarias. Entre los católicos romanos hay ya muchos que son más ilustrados que sus antepasados y que han renunciado a muchos de esos usos que antiguamente eran sagrados". ${ }^{5}$

Queda, en fin, la posibilidad de una superstición secularizada, en la que cabrían las todavía muy extendidas aprensiones, creencias o prácticas que no se sustentan en la razón, y que con frecuencia nada tienen que ver con religión alguna. ${ }^{6}$

Nada más deleznable, y por ende poco científico, que el término "superstición", a menudo una mera arma arrojadiza desde los poderes constituidos o frente a la alteridad que se rechaza. Y, sin embargo, como bien advirtió Julio Caro Baroja, "no deja de ser provechoso el examinar sus rasgos equívocos a lo largo de los siglos y dentro de distintas sociedades". 7

Este trabajo pretende acercarse a dicha equivocidad, al uso polisémico de este término y al vivo debate que provocó en la España de la segunda mitad del siglo XVIII, cuando el despotismo más o menos ilustrado se empeñó en depurar las ceremonias y fiestas religiosas de sus elementos considerados supersticiosos, o al menos impropios o excesivamente profanos; una tarea que, como se constata en el caso concreto de la catedral de Toledo, ya había sido iniciada por los reformadores tridentinos de los siglos XVI y XVII.

Para entender el debate ilustrado sobre la superstición y la religiosidad es, no obstante, indispensable rastrear la arqueología de ambos términos y la evolución en el tiempo de sus mutuas relaciones, normalmente de oposición, aun cuando la frontera entre ambas fuese, como ya se ha dicho, siempre difusa.

4 Voltaire, F.M.A. 2000. Diccionario filosófico, 560-562. Madrid: Temas de Hoy.

5 Ibídem, 560

6 Por ejemplo, esta definición secundaria de la Gran Enciclopedia Larousse: "Creencia en vanos presagios producidos por acontecimientos puramente fortuitos (salero volcado, número trece, etc.)".

7 Para Julio Caro Baroja, el vocablo superstición "resulta esencia para estudiar muchos tipos de sociedades, los puntos de vista que tienen sobre sí mismas y los argumentos que usan contra otras, enemigas o rivales". (1981. De la superstición al ateísmo. Meditaciones antropológicas, 151 y 162. Madrid: Taurus).
La empresa se vuelve complicada en lo que respecta a la etimología, pues el término griego "deisidaimonía" (temor de Dios, piedad, superstición) tiene una raíz por completo diferente a la palabra latina "superstitio", que no puede ser más enigmática. ${ }^{8}$ No resulta muy convincente, o al menos no me lo parecen las interpretaciones que se han hecho a partir de ella, la explicación dada por Cicerón, que la hace derivar de "superstes", o sea, "verdadero testigo de lo pasado" o, también, "superviviente": "las personas que pasan los días enteros en la plegaria y los sacrificios para asegurar que sus hijos las sobrevivan". ${ }^{9}$ Otra hipótesis hace provenir el vocablo del verbo "superstare", que se refiere a "lo que está por encima" (¿lo sobrenatural?), como se deduce de una famosa cita de Lucrecio. ${ }^{10}$ En ella, aparte de las "superstantium rerum" y del "timor" (temor a los dioses), destacan dos cualidades de lo supersticioso que en adelante siempre irán unidas a este término: "inanis", que puede traducirse por "vacío" o "vano", y "superfluus".

Pero las referencias del mundo antiguo más influyentes en los siglos posteriores fueron sendas obras de Cicerón y Plutarco. El primero hizo debatir a tres filósofos (un epicúreo, un académico y un estoico) sobre la naturaleza de los dioses, que es exactamente el título del ensayo. En el libro I el académico Cota, portavoz del autor, considera las creencias del vulgo "un simple amasijo de incongruencias nacidas de la ignorancia de la verdad", ${ }^{11}$ y es en esa ignorancia donde encuentran terreno abonado las supersticiones, muy en particular la adivinación. Lo más interesante, sin embargo, es la distinción que hace Cicerón entre la superstición, "que implica un temor infundado a los dioses", y la religión, "que consiste en venerarlos piadosamente".12 Los supersticiosos, obsesionados por su temor, pasan el día entero en la plegaria y los sacrificios; los verdaderamente religiosos, en cambio, veneran piadosamente a los dioses con pureza, sinceridad e inocencia. "De aquí los términos 'supersticioso' y 'religioso' pasaron a ser términos de censura y aprobación, respectivamente"..$^{13}$ En otra de sus obras, Sobre la adivinación, aboga Cicerón por la erradicación de la superstición, pues ésta ha oprimido los espíritus y se ha enseñoreado de la debilidad humana; ${ }^{14}$ pero dejando claro que la religión

\section{Ibídem, 152.}

9 Cicerón. 1970. Sobre la naturaleza de los dioses, libro II, cap. 28, 160. Buenos Aires: Aguilar Argentina. Del mismo modo Cicerón hace derivar el término "religión" de "re-legere" y lo aplica a la relectura y revisión cuidadosa del saber ritual. La procedencia más lógica es, sin embargo, la de "re-ligare", que luego recogería san Isidoro en sus Etimologías (1982, t. I, 689. Madrid: B.A.C.): "La religión recibió este nombre porque, mediante ella, 'religamos' nuestras almas al único Dios para rendirle culto por el vínculo de servicio con Él establecido. Este vocablo se ha formado a partir de 're-elegir', es decir, de 'elegir', de manera que, en latín, 'religión' viene a ser 'elección'”. En esto último sí concuerda san Isidoro con Cicerón.

10 "Superstitio est superstantium rerum, id est caelestium et divinarum, quae super nos stant, inanis et superfluus timor". Cit. por Caro Baroja, J. 1981: 154.

11 Cicerón. 1970: 56.

12 Cicerón. 1970: 103.

13 Cicerón. 1970: 160-161.

14 Cicerón. 1999. Sobre la adivinación. Madrid: Gredos. "Los vástagos de la superstición han de ser arrancados todos ellos, porque la superstición te acucia, te urge, $y$, a donde quiera que te dirijas, te persigue (...), ya estés atendiendo a un vate o a un presagio, ya te dediques 
no sólo debe mantenerse, sino aún propagarse, "pues lo propio del sabio es mirar por las tradiciones de los mayores, mediante la conservación de los ritos sagrados y de las ceremonias". ${ }^{15}$ Para Cicerón, pues, la superstición vulgar e ignorante es contraria a la religión oficial y debidamente regulada por los poderes cívicos. ${ }^{16}$

Por su parte, Plutarco introduce un nuevo elemento en la relación (u oposición) antedicha, configurando así una tríada que seguirá conservando su actualidad muchos siglos después. En ella, la religión o piedad, como tal virtud, quedará en una posición intermedia entre dos extremos:

"Algunos, al huir de la superstición, van a caer en un ateísmo cruel y obstinado, saltando por encima de la piedad que se encuentra situada en medio". ${ }^{17}$

Ambos extremos se alejan de la virtud, pues "el ateísmo es una indiferencia hacia la divinidad, que no conoce el bien, y la superstición es una multitud de sensaciones que supone que el bien es malo". ${ }^{18}$ Los espíritus "fuertes" suelen terminar incurriendo en la impiedad, mientras que los "caracteres blandos" son más propensos a la superstición. Caer en el ateísmo es una gran desgracia, pues impide el conocimiento de la divinidad, fuente de todo bien, pero Plutarco pone aún en peor lugar a la superstición, que degrada al hombre y le arrebata su dignidad al sumirle en el "más impotente y embarazoso de todos los temores", pues "el que teme a los dioses teme a todas las cosas, a la tierra, al mar, al aire, al cielo, a la oscuridad, a la luz, al rumor, al silencio, al sueño". ${ }^{19}$

La distinción entre religión y superstición, y el juego de relaciones

ateísmo (o impiedad)-religión (o piedad)-superstición

son los ejes de las discusiones y debates que hereda el cristianismo, si bien desplazando de su posición central a la religión pagana (a la que definitivamente se confunde con la superstición) en favor de la "religión verdadera". Para Lactancio, en efecto, "Religio veri cultus est, superstitio falsi". ${ }^{20}$ Y san Agustín, en La ciudad de Dios, mete en el mismo saco supersticioso a las religiones de los egipcios,

a inmolar o a observar un ave, si ves a un caldeo o a un arúspice, si relampaguea, si truena, si se produce una descarga del cielo, si se produce cualquier nacimiento o suceso que se asemeje a una aparición" (268-269).

15 Cicerón. 1999: 268.

16 Véanse las interpretaciones de Domínguez García, V. 1993. “La ciudad acosada", en M. Pérez Álvarez (comp.), La superstición en la ciudad: 299-306. Madrid: Siglo XXI. Y de Caro Baroja, J. 1981: 153. Para este último, la superstición clásica implica "interés personal, egoísmo, superfluidad, vanidad, debilidad (senil o femenina), ilegitimidad, extranjería, enemistad, adulación, ignorancia o incultura y exceso, en suma" (161).

17 Plutarco. 1986. Sobre la superstición, en Obras morales y de costumbres (Moralia): 320. Madrid: Gredos.

18 Ibídem, 302. La superstición "es una opinión emocional y una creencia que produce un miedo que humilla y desalienta al hombre que cree que los dioses existen, pero que son adversos y funestos" (291). "Para el supersticioso, toda enfermedad del cuerpo, pérdida de riquezas, muertes de hijos, desgracias y fracasos en los asuntos públicos, quieren decir golpes de la divinidad y ataques de un espíritu" (304). Cuando un hombre cae en la superstición, "confunde y ciega la razón en hechos que están necesitados, sobre todo, de la razón" (308).

19 Ibídem, 292.

20 Caro Baroja, J. 1981: 162. caldeos, judíos, gentiles, y también la de los romanos, a la que tilda de "cruel", "perniciosa", "envejecida", "vana", "sacrílega" y "propia de viejas". Al obispo de Hipona ya no le vale la distinción efectuada por Cicerón, ya que su supuesta religión no es sino la superstición que critica, en tanto que consiste en adorar las estatuas de los falsos dioses o demonios. La frontera entre ambas, antes no demasiado clara, ahora se aparece nítida, como lo es la que separa a la ciudad de los hombres de la ciudad de Dios, al paganismo de la verdadera y única religión. ${ }^{21}$

Dos siglos más tarde san Isidoro de Sevilla sintetiza todo este patrimonio etimológico, tanto en lo que respecta a la religión (en sus acepciones de "religar" y "elegir") como a la superstición, a la que define como "creencia superflua o sobreinstituida".22

Pero será santo Tomás de Aquino el que sistematice, en la "Secunda Secundae" de su Suma Teológica, todos los matices que el mundo antiguo y los Padres de la Iglesia habían incorporado al concepto de superstición, ofreciendo al porvenir unos criterios de autoridad estructurados y adaptados a las necesidades del cristianismo. Empieza definiendo a la superstición como "el exceso en la práctica de la religión", y puesto que ésta es una virtud moral, y "toda virtud moral consiste en el justo medio", se diferencia de los dos vicios extremos: por un lado, el exceso (la superstición); por otro, el defecto (la irreligión). Volvemos de este modo al esquema de Plutarco: "Así, pues, la superstición es un vicio opuesto a la religión por exceso, no porque ofrezca a Dios más, en lo que a culto divino se refiere, que lo que la verdadera religión le ofrece, sino por el hecho de rendir culto divino a quien no debe o del modo que no debe". ${ }^{23}$

Estas precisiones finales son de suma importancia por cuanto permiten precisar aún más el concepto y distinguir varias clases de supersticiones. Rendir culto a quien no se debe es idolatría. Hay, pues, una superstición idolátrica (cuestión 94). Pero también se puede dar culto al verdadero Dios de modo indebido, en cuyo caso se incurriría en la superstición adivinatoria (cuestión 95) o en la de vanas observancias, o sea, cultos o ceremonias perniciosos, porque tienen que ver con la antigua ley o con ritos contrarios a los establecidos por la Iglesia, y superfluos, porque son actos exteriores que nada tienen que ver con la gloria de Dios, ni con la elevación de nuestra mente hacia Él, o que están al margen de las costumbres o leyes de Dios y de la Iglesia (cuestión 93). Serían, así, prácticas supersticiosas

21 San Agustín, La Ciudad de Dios, en Obras. Disponible en http:// efrueda.com/wp-content/uploads/2011/12/L-a-ciudad-de-Dios.pdf, $<11$ de enero de 2016>. Las alusiones a la superstición están dispersas en los libros II, IV, VI, VII, VIII, XVI, XVIII, XXI y XXII.

22 San Isidoro. 1982: t. I, 688-691. El autor rechaza la etimología propuesta por Lucrecio ("superstantes") y cita sin criticarla la de Cicerón, que relaciona el término con los ancianos que "en razón de sus muchos años, deliran y yerran con alguna superstición, por desconocimiento de qué cultos antiguos han de realizar o por ignorancia de cuál de las prácticas tradicionales han de adoptar". Superstición, pues, como cosa de viejos y de ignorantes.

23 Santo Tomás de Aquino, Summa Theologica, Parte II-Ilae, cuestión 92, artículo I. Disponible en http://www.documentacatholicaomnia. eu/03d/1225-1274,_Thomas_Aquinas,_Summa_Theologiae,_ES.pdf, $<11$ de enero de $2016>$. 
las destinadas a la adquisición de ciencia, a la mutación de algunos cuerpos, a averiguar por conjeturas la buena o mala ventura, y las fórmulas sagradas que se llevan al cuello (cuestión 96).

Los autores católicos de la España del siglo XVı parten casi todos de las ideas de san Isidoro y santo Tomás, como el demonólogo Martín del Río ${ }^{24}$ o los especialistas en supersticiones y hechicerías, Pedro Ciruelo y Martín de Castañega. En todos estos tratados se hace, si acaso, un mayor hincapié en el protagonismo del diablo, no sólo porque está detrás de toda idolatría, sino porque "todas las supersticiones y hechicerías vanas las halló y enseñó el diablo a los hombres". ${ }^{25}$ Puede servir como definición actualizada a los nuevos tiempos el siguiente párrafo de Pedro Ciruelo:

"toda obra que el hombre hace para haber algún bien o para excusar algún mal, si las cosas que allí pone y las palabras que allí dice no tienen virtud natural ni sobrenatural para hacer aquel efecto, aquella operación es vana, supersticiosa y diabólica; y si viene a efecto es por secreta operación del diablo". ${ }^{26}$

Las supersticiones adivinatorias, como las denominara el Aquinate, pueden implicar pacto con el diablo (la nigromancia) o un pacto encubierto (geomancia, quiromancia, etc.); pero también las vanas observancias que se emplean para alcanzar bienes o evitar males han de contar, para ser efectivas, con el concurso del diablo. Y Ciruelo acaba proponiendo la siguiente clasificación:

"Quedan, luego, reducidas todas las supersticiones a cuatro especies principales, y son éstas: Nigromancia, Adivinación, Ensalmo y Hechicería". ${ }^{27}$

Todas las cuales, por supuesto, entrarían dentro de la jurisdicción inquisitorial. Sin embargo, la frontera entre lo supersticioso y lo que no lo es, desde el punto de vista institucional, no está tan claro, si atendemos a las reflexiones de Martín de Castañega, para quien no todos los conjuros eran rechazables. Había una manera católica de conjurar las nubes y tempestades, o de exorcizar demonios; tampoco consideraba hechiceros a los sanadores y pensaba que el aojar era cosa natural. Por todo lo cual aconsejaba que "dexen las supersticiones y invocaciones diabólicas y tomen las que son seguras, devotas y católicas". ${ }^{28} \mathrm{El}$ control de los ritos y ceremonias se revela, pues, cuestión fundamental cuando en el mundo católico se trazan los límites de la superstición, a la que, por toda definición, calificó Covarrubias en su diccionario de "falsa Religión, y error necio". ${ }^{29}$

\footnotetext{
24 Martín del Río. 1991. La magia diabólica: 119. Madrid: Hiperión.

25 Pedro Ciruelo. 2005. Reprobación de las supersticiones y hechicerías (1538): 25 . Valladolid: Maxtor.

26 Ibídem, 28.

27 Ibídem, 34.

28 Martín de Castañega. 1994. Tratado de las supersticiones y hechizerías y de la possibilidad y remedios dellas (1529): 64. Logroño: Instituto de Estudios Riojanos.

${ }_{29}$ Y continúa: "que comúnmente suele caer en vegeçuelas embaucadoras, que hazen de las muy santas". Y después remite al Padre Martín del Río y a la Natura deorum de Cicerón. Covarrubias y Horozco, S. de. 1995. Tesoro de la lengua castellana o española. Madrid: Castalia.
}

\section{EL PAÍS DEL FANATISMO Y LA SUPERSTICIÓN}

$\mathrm{Si}$, como ha señalado un historiador, el de la religiosidad fue "el debate más decisivo de la Ilustración en la España de Carlos III", ${ }^{30}$ no es descaminado pensar que también lo fue el debate sobre la superstición, en referencia a la cual la religión precisaba su centralidad o su genuina identidad. Y, en efecto, es un término vapuleado y objeto de muy distintas críticas y desde intereses también muy diferentes, un fantasma que llena páginas y páginas en los escritos de autores literarios, ensayistas, periodistas, satíricos, viajeros, predicadores, reformistas y contestatarios.

Unas veces, la mirada externa, la de los viajeros extranjeros que recorrían España, chocaba violentamente con la percepción de los naturales; en otros casos, los ilustrados más críticos asumían los juicios de los observadores foráneos y los utilizaban para mejor fundamentar sus ansias de reforma. En todas estas miradas (la crítica autosuficiente de algunos viajeros, el comprensivo acuerdo de algunos ilustrados, la indignada reacción de la mayoría) pesó decisivamente la opinión de los filósofos, quienes no sólo hicieron valer sus concepciones de lo que era religioso y supersticioso, sino que también contribuyeron a que se viese en España al país del atraso y de la superstición.

Voltaire fue una de las plumas más influyentes en Europa y, pese a las condenas de que su obra fue objeto, también en España. ${ }^{31}$ Sus ideas religiosas se resumen de forma nítida en la definición que de la superstición incluyó en su Dictionnaire Philosophique portatif de 1764:

"Presque tout ce qui va au-delà de l'adoration d'un être supreme, et de la soumission du coeur à ses ordres eternels, est superstition". ${ }^{32}$

No era, pues, un ateo, como tan a menudo le reprocharon sus detractores. Voltaire conservó, por el contrario, la tríada de Plutarco y de santo Tomás con la religión, debidamente depurada de extremismos, en el centro del esquema. En su Tratado de la tolerancia, y en desacuerdo con Plutarco, mantuvo que, en determinados estadios de la evolución humana, era preferible la superstición a la irreligión, pues constituía un freno a sus peores instintos;

30 Egido, T. 1988. "Actitudes religiosas de los ilustrados", en Carlos III y la Ilustración: 225. Madrid: Ministerio de Cultura/ Lunwerg. Del mismo autor, 1990. "La religiosidad de los españoles (siglo XVIII)", en Coloquio Internacional "Carlos III y su siglo", vol. I, 767-792. Madrid: Universidad Complutense.

31 Ver Defourneaux, M. 1973. Inquisición y censura de libros en la España del siglo XVIII: 160. En 1762 la Inquisición condenó las obras completas de Voltaire por "contener proposiciones respectivamente heréticas, erróneas, escandalosas y temerarias que inducen al deísmo y al materialismo, con notable perjuicio de la religión y experimento de ruina de almas". Todavía a fines del siglo XIX escribiría Marcelino Menéndez y Pelayo en su Historia de los heterodoxos españoles (1987: t. II, 323324) que Voltaire sería recordado como "símbolo y encarnación del espíritu del mal en el mundo" y lo presentaba como un "entendimiento mediano, reñido con la metafísica y con toda abstracción; incapaz de enlazar ideas o de tejer sistemas, ha dado su nombre, sin embargo, a cierta depravación y dolencia del espíritu, cien veces más dañosa a la verdad que la contradicción abierta".

32 Voltaire, F.M.A. 1819. Dictionnaire Philosophique Portatif, en Oeuvres complètes de Voltaire: vol. VI, 335. París: Chez Antoine-Augustin Renouard. 
pero, "una vez que los hombres han llegado a abrazar una religión pura y santa, la superstición se vuelve no sólo inútil, sino muy peligrosa". Poco a poco, la razón iba desarraigando las supersticiones, entre ellas la más peligrosa, la de odiar al prójimo por sus opiniones. ${ }^{33}$ Aún así, advertía en el Diccionario Filosófico que seguimos rodeados de supersticiones, y ponía como ejemplo "esas procesiones de flagelantes en Italia y en España, que van cantando y dándose disciplinazos a la vista del público", como si "el paraíso se conquistase a latigazos". ${ }^{34}$ No es la única alusión que Voltaire hizo a España a lo largo de su extensa obra. En el diccionario "portátil" antes citado, hace un Ilamamiento a los españoles para que "los nombres de la Inquisición y de la Santa Hermandad (sic) no vuelvan a ser pronunciados". ${ }^{35} \mathrm{Y}$ Menéndez Pelayo se hace eco de sus acusaciones a la tiranía monacal y a que España había sido un país en que la libertad era mirada como un crimen y donde los jesuitas vedaban el cultivo de la razón. Afortunadamente, siempre según las apreciaciones del filósofo francés, el conde de Aranda había comenzado a rasgar la venda de las supersticiones y a cortar las cabezas de la hidra de la Inquisición. ${ }^{36}$

Pero la conmoción mayor que experimentó la opinión pública española fue provocada por la pluma de un escritor de segunda fila, Nicolás Masson de Morvilliers, cuando en 1782 publicó un artículo sobre España en la Encyclopedie Methodique. En él no aparecía el término superstición, pero se pintaba a los españoles como indolentes, perezosos y apáticos, y al país como "un pueblo de pigmeos" y "la nación más ignorante de Europa", para concluir con una pregunta retórica e inmensamente despreciativa:

"Mais que doit-on à l'Espagne? Et depuis deux siècles, depuis quatre, depuis dix, qu'a-t-elle fait pour l'Europe?"37

Qué duda cabe que muchos viajeros vinieron a España pertrechados por prejuicios de este o semejante jaez, que sus lecturas habían alimentado. Algunas de ellas eran, incluso, anteriores a los juicios de los filósofos ilustrados, como las descripciones que la condesa d"Aulnoy hiciera de las corridas de toros, los autos sacramentales o los disciplinantes de Semana Santa; ${ }^{38}$ o el relato del "affreux spectacle" del auto de fe de 1680, a cargo de los marqueses de Villars. ${ }^{39}$

Por supuesto, muchos de estos viajeros vieron confirmados estos prejuicios por sus propias observaciones.

33 Voltaire, F.M.A. 2002. Tratado sobre la tolerancia: 169-172. Madrid: Espasa-Calpe (Capítulo XX: "De si es útil mantener al pueblo en la superstición").

${ }^{34}$ Voltaire, F.M.A. 2000. Diccionario filosófico: 556. Madrid: Temas de Hoy.

35 Voltaire, F.M.A. 1819: 314.

36 Menéndez Pelayo, M. 1987. Historia de los heterodoxos españoles: t. II, 487-491. Madrid: B.A.C.

37 Encyclopedie Methodique, 1782: t. I, 556 y 564-565. París: Chez Panckoucke Libraire. Y, como un remedo de Voltaire, Masson incluía una dura crítica anticlerical: "Que peut-on espérer d'un peuple qui attend d'un moine la liberté de lire et de penser?".

38 Madame D’Aulnay, 1892. Viaje por España (1679). Madrid: Tipografía Franco-Española.

${ }_{39}$ Marquis de Villars. 1893. Mémoires de la Cour d'Espagne de 1679 à 1681: 186-189. París: Plon. Y Marquise de Villars. 1922. Lettres de la Marquise de Villars: 95. París: Librairie Ollendorff. La expresión es de la marquesa de Villars en su carta del 25 de julio de 1680.
Es materia común de sus memorias la crítica de las malas posadas, el miedo a los salteadores de caminos, el excesivo y oscurantista poder de los frailes, el rechazo (y en algún caso fascinación) de las fiestas de toros, los horrores de la Inquisición, y naturalmente la superstición que a sus ojos impera por doquier. ${ }^{40}$ En 1722 el duque de Saint-Simon trata de evitar todo escándalo "en un país dominado por la superstición". ${ }^{41}$ Beaumarchais vio en las costumbres populares, derivadas de los usos moros, "un resalte de sinrazón y cinismo que no se encuentran en otras partes", ${ }^{42}$ mientras que un viajero francés que recorrió el país en 1765 aseguraba que "cuanto más se hunde uno en España, más se encuentra la ignorancia y la superstición". ${ }^{43}$ Aún más duro se muestra en su juicio el sueco Creutz, que, en una carta a Marmontel, se siente transportado diez siglos atrás:

"El pueblo, cuya subsistencia está devorada por los frailes, aplastado bajo el peso inmenso de la superstición y del poder arbitrario, se corrompe en la miseria y en la holgazanería, y ni siquiera tiene la fuerza para gemir por ello".44

Testimonios parecidos se encuentran en viajeros de todas las religiones y nacionalidades. El británico William Dalrymple se lamentaba de que "todavía prevalecen aquí el fanatismo religioso y la superstición", ${ }^{45}$ y su compatriota, el reverendo Joseph Townsend, aun saludando que Europa estuviese saliendo del dominio de la superstición y de la "ignorancia goda", mostraba su confianza en que España, "aunque la última, no sea la que menos se despoje de ella". ${ }^{46}$ Pero el alemán Wilhelm von Humboldt, cuando el siglo daba sus últimas boqueadas, defraudaba esta esperanza al constatar que "en ningún país católico el pueblo es tan ignorante en lo que a religión atañe" y, más aún, "los sacerdotes no se esfuerzan en eliminar la superstición" ${ }^{47} \mathrm{Y}$, por parte de Francia, Peyron ponía en un mismo saco a Italia y España como reservorios de la superstición y el fanatismo, directa herencia de romanos y godos. ${ }^{48}$ Para Jean-François Bourgoing, que publicó el relato de sus viajes y luego reeditó una versión ampliada bajo el título de Tableau de l'Espagne moderne, la nación española, salvo algunas recientes

40 Sobre los viajeros extranjeros en la España del siglo XVIII ver García Mercadal, J. 1999, Viajes de extranjeros por España y Portugal. Desde los tiempos más remotos hasta comienzos del siglo xx: tt. IV-V. Salamanca: Junta de Castilla y León. También Guerrero, A. C. 1990. Viajeros británicos en la España del siglo XVIII. Madrid: Aguilar. Y Robertson, I. 1988. Los curiosos impertinentes. Viajeros ingleses por España desde la accesión de Carlos III hasta 1855. Madrid: Ed. del Serbal/C.S.I.C.

41 Cit. García Mercadal, 1999: t. IV, 712.

42 Ibídem, t. V, 43. Carta al duque de La Vallière, Madrid, 24 diciembre 1764 .

43 Ibídem, t. V, 88. La relación de este viaje, anónima, se conserva manuscrita en la Biblioteca Mazarino.

44 Ibídem, t. V, p. 107. El conde Gustav Philip Creutz era ministro de Suecia.

45 Cit. Robertson, I. 1988: 92.

46 Townsend, J. 1988, Viaje por España en la época de Carlos III (1786-1787): 54. Madrid: Turner.

47 Humboldt, W. von. 1998. Diario de viaje a España, 1799-1800: 88-89. Madrid: Cátedra. Su viaje data de 1799-1800.

48 Peyron, J.F. 1782. Nouveau Voyage en Espagne, fait en 1777 et 1778, 1782: t. II, 140. Londres: Chez P. Elmsly. De los españoles dice que "ils sont superstitieux et dévots de bonne foi, accoutumés, dès leur enfance, à la credulité et aux ceremonies de la pièté" (143). 
excepciones, estaba todavía sumida en creencias devotas y en mascaradas ("momeries") religiosas, en una palabra, era "justamente acusada de superstición", a la que consideraba "hermana bastarda de la religión desfigurada". 49

Entre todos estos denunciantes de la superstición ajena encontramos actitudes comprensivas y curiosas, pero también otras que se antojan excesivamente intolerantes, lo que resta a sus observaciones parte de su interés. Buena muestra de ello es el caso del británico Richard Twiss, que en el prefacio al relato de su viaje por España incluyó una loable declaración de intenciones:

\footnotetext{
"Por lo que se refiere a las pocas frivolidades en cuanto al tema de la superstición, no he intentado ridiculizar a las personas creyentes, sino a los objetos de su creencia, ya que no podemos condenar con razón a la humanidad por diferir en sus opiniones; todos buscamos la verdad, pero sólo Dios sabe quién la ha encontrado". ${ }^{50}$
}

Pero el prejuicio de Twiss mata en él toda curiosidad, que es siempre la motivación del buen viajero. Desprecia la misa por absurda, rechaza que le muestren reliquias, que le cuenten milagros, y cuando se entera de que en Toledo va a celebrarse una procesión "con todas las estatuas de plata y monjes en la ciudad", se apresura a marcharse porque "este tipo de exhibiciones no han sido nunca mi pasatiempo favorito". ${ }^{51}$

Entre las supersticiones criticadas por los extranjeros aparece alguna vez la idolatría, tal como la veían los protestantes en las prácticas católicas. Así, Edward Clarke descubrió tal profusión de santuarios, cruces, altares, "y en particular tal abundancia de imágenes", que "estoy convencido de que si uno escupe por la ventana en España, hay diez probabilidades contra una de darle a un santo". ${ }^{52}$ Pero la mayor parte de sus andanadas van dirigidas contra lo que autoridades en el tema habían designado "vanas observancias". Bourgoing aprobó de forma entusiasta la proscripción de los autos sacramentales, "où les Anges, les Saints, les Vertus personnifiées, jouoient leur rôle au scandale de la religion et de la raison". ${ }^{53}$ También se ridiculiza con frecuencia la credulidad en los milagros: hay tantos, y son tan cotidianos, que "no hay santo, por pequeño, por humilde que sea, que no cure, que no madure las uvas, que no haga ganar dinero, y eso produce un número prodigioso de peregrinaciones, de votos, de misas y de beneficios". ${ }^{44}$ Igual rechazo concitan las reliquias, que Twiss tilda de "vil engaño"; Clarke, de absurdo que "acaba por ser risible"; y Bourgoing se burla de los grandes que atesoran reliquias entre las joyas familiares. ${ }^{55}$

49 Bourgoing, J.F. 1789. Nouveau Voyage en Espagne, ou Tableau de l état de cette Monarchie. París: Chez Regnault. Y del mismo autor, 1803. Tableau de l'Espagne Moderne. París: Chez Levrault Frères.

50 Twiss, R. 1999. Viaje por España en 1773: 49. Madrid: Cátedra.

51 Para gran disgusto de su calesero, "que de esta forma se perdía la bendición del arzobispo, o se libraba de ella". Ibídem, 134-135. Se trata de una de las procesiones de Semana Santa, pues la visita de Twiss a Toledo se fecha en 8 de abril de 1773 .

52 Cit. Robertson, I. 1988: 42-43.

53 Bourgoing, J.F. 1789: 358.

54 En el viaje anónimo de la Biblioteca Mazarino cit. por García Mercadal, J. 1999: t. V, 85.

55 Twiss. 1999: 60; Clarke en Robertson, I. 1988: 42; Bourgoing, J.F. 1803: 301.
Las procesiones son a menudo consideradas perfectas visualizaciones de la superstición y el fanatismo. Dalrymple hizo notar que "por las calles transcurren procesiones sin cuento, a las que el pueblo es muy dado, inclinación que el clero cuida de fomentar". ${ }^{56}$ Comentando la procesión del Corpus que vio en Barcelona, Norberto Caimo se burló de que "hay en ellas tantas locuras y cosas ridículas, que cuesta trabajo no reventar de risa". ${ }^{57}$ Otro viajero juzgó extravagantes las procesiones en que participaban gigantes y monstruos, una buena prueba de que "la caballería y lo maravilloso son la base de todos los milagros de los santos cristianos", y concluía:

"Todas esas señales de superstición no se ven ya en el resto de Europa sino con indiferencia y desprecio, como viejos abusos que dejaron subsistir por política, porque son espectáculos que atraen y ocupan al pueblo, cuyo concurso ocasiona una circulación de dinero que produce un beneficio real a cada ciudad que tiene la dicha de tener una procesión famosa". ${ }^{58}$

Pero las procesiones que provocaron mayor rechazo fueron las de disciplinantes. "Los flagelantes españoles escribió Edward Clarke, espantado- son un espectáculo horrible"; el viajero anónimo describe a los penitentes "cubiertos de un lienzo desde los pies a la cabeza, bañados en su sangre, que corre y gotea"; Peyron cuenta que vio a numerosos devotos, "le visage masqué, et nus jusqu'à la ceinture, se flageller, et faire jaillir de leur corps des ruisseaux de sang"; ${ }^{99}$ y Townsend, al relatar un miserere de flagelantes, pinta un cuadro de horror que anuncia las alucinadas pinturas de Goya:

"A los veinte minutos se había perdido cualquier posibilidad de distinguir los sonidos y todo terminó en un profundo gemido. Aunque estaba preparado para encontrar algo terrible, esto superó de tal manera mis expectativas que se me heló la sangre; y uno del grupo, que no se caracterizaba por tener los nervios sensibles, rompió a llorar al encontrarse con semejante espectáculo sin esperarlo".60

En las procesiones, en fin, chocan las danzas que en ellas se intercalan con aparente naturalidad. Caimo no salía de su asombro cuando, en medio de la procesión del Corpus de Barcelona, vio a los gigantes que, con figuras de hombres y mujeres, de mulos, águilas, leones y otras bestias semejantes, "marchan con gravedad y, de tiempo en tiempo, bailan en medio de los gritos de alegría del populacho"; y Lantier comprobó en Madrid que "todavía hay procesiones en las que los hombres y las mujeres bailan juntos ante la imagen de la Virgen, al son de las castañuelas y de otros instrumentos". ${ }^{61}$

56 Cit. Robertson, I. 1988: 93.

57 Cit. García Mercadal, J. 1999: t. IV, 765.

58 En el viaje anónimo de la Biblioteca Mazarino, cit. por García Mercadal, J. 1999: t. V, 84-85.

59 Clarke en Robertson, I. 1988: 43; el viajero anónimo y Peyron, ibídem, t. V, 85 y 160 respectivamente.

60 Townsend, J. 1988: 58. Y termina con el siguiente juicio: “a juzgar por lo generalizado que está el vicio en España, me temo que esta costumbre tiene muy poca o ninguna utilidad para la reforma de la moral del país".

61 Cit. García Mercadal, J. 1999: t. IV, 765; y t. V, 770. 
El reformismo carolino, haciéndose eco de estas críticas, trató de sanear las ceremonias y fiestas religiosas eliminando algunas de estas excrecencias impropias, vanas, profanas y por todo ello supersticiosas. Los viajeros saludaron con alborozo todas estas medidas que daban un paso más para sacar a España del atraso y de la ignorancia. Townsend se felicitaba de que "hoy día ya no se usan en las procesiones una serie de costumbres que se habían introducido furtivamente". "El magistrado civil -en efecto- ha prohibido, usando de su autoridad y bajo la amenaza de las penas más severas, abominaciones que constituyen auténticos frutos del vicio". Y Peyron tuvo la fortuna de que su estancia en el país coincidiese con la promulgación de una de estas medidas:

“Dans l'année 1777, le roi a trouvé mauvais qu'on se masquât, qu'on se fouettât, qu'on dansât, et qu'on allât les bras en croix. II a fait défendre toutes ces actions pieuses sous des peines três graves, et les processions n'ont pas été si ridicules de moitié". ${ }^{62}$

Pero si damos crédito a uno de los análisis más profundos que pueden encontrarse dentro del género de la literatura de viajes, el efectuado por el diplomático Jean-François Bourgoing, los resultados de este reformismo se antojan harto escasos. Bourgoing también fue testigo de las reformas carolinas y se hizo la ilusión de que las luces estaban penetrando lentamente en España, pero no se le ocultaba que el mismo Carlos III pagó hasta su muerte un tributo a la superstición como un crédulo devoto más, cual lo demostraba, por ejemplo, su fe ciega en la licuefacción de la sangre de san Jenaro en Nápoles. Y si así era su rey, mucho más alarmante se aparecía la situación del pueblo sumido en la ignorancia:

"Mais dans les classes où l'éducation est négligée (et elles sont nombreuses), où l'on a peu de communication au dehors, peu de moyens de s'éclairer, la superstition et le fanatisme sont encore portés à un degré d'exaltation qu'on trouve à peine en Flandre et en Bavière".

Bourgoing aplaudió las reformas llevadas a cabo por los ministros carolinos, que despojaron a la sana religión de ceremonias inútiles, que preservaron a la autoridad temporal de las usurpaciones de la Iglesia, que disminuyeron el prodigioso número de conventos. Pero nadie se debía llamar a engaño sobre el calado de estas reformas, bienintencionadas pero insuficientes, y "on ne dit donc rien de calomnieux quand on affirme que I'Espagne est encore, à beaucoup d'égards, la patrie des momeries, le pays du fanatisme et de la superstition". ${ }^{63}$

\section{LA RELIGIÓN ENTRE LA IMPIEDAD Y LA SUPERSTICIÓN}

Si los viajeros románticos creyeron descubrir una España pintoresca y exótica, los ilustrados, un siglo antes, buscaron y encontraron el país del fanatismo y la superstición. Pero no se trató solamente de acusaciones provenientes de extranjeros prejuiciosos; la superstición estuvo también en

\footnotetext{
62 Townsend, J. 1988: 54; Peyron, J.F. 1782: 161.

63 Bourgoing, J.F. 1789: 258; y sobre todo, Idem, 1803: 298-314.
}

el centro de un debate muy vivo que se dirimió entre españoles, fuesen eclesiásticos o seglares, ilustrados o tradicionalistas, reformistas o contestatarios.

En la medida en que pudieron ser conocidas, influyeron en este debate las doctrinas de los filósofos, y muy en especial el famoso artículo de la Encyclopedie Méthodique, que provocaría varias reacciones en forma de apologías. Pero los antagonistas se apoyaron en mayor medida en la tradición clásica y cristiana. Cuando, en su tomo VI, el Diccionario de Autoridades ha de definir la voz "Superstición", lo hace de acuerdo con el tomismo más ortodoxo: "Culto que se da a quien no se debe con modo indebido",64 y entre las citas a que recurre para aclarar el adverbio "supersticiosamente" figura el Teatro Crítico del benedictino fray Benito Feijoo, figura que ayudó a centrar el debate y que se convirtió en la principal referencia del mismo en la segunda mitad del siglo XVIII. Feijoo ha pasado a la historia como uno de los primeros adalides de la razón y el debelador de las supersticiones por excelencia. Y, en efecto, en los ocho volúmenes de su Theatro Crítico Universal, clamó contra las impropiedades de la música sagrada, que con sus minuetos, recitados, arietas y alegros en poco se diferenciaba de la que se escuchaba en los saraos; contra los supuestos milagros, las extravagancias de las tradiciones populares conservadas "a la sombra del vano pero ostentoso título de tradición", y contra las profanidades que manchaban el blanco velo de la religión. ${ }^{65}$ No obstante, el pensamiento del benedictino es bien poco original. Al hablar del toro de San Marcos ofrece una definición de la superstición extraída claramente de la Suma de santo Tomás:

"El pecado de superstición, tomado genéricamente, en dos diferentes especies. La una consiste en dar culto religioso a quien no se debe; la otra en darle a quien se debe, pero con el modo que no se debe. La primera se comete, dando culto a cualquier criatura, como si fuese Deidad; la segunda, dando a Dios, o a sus Santos un culto vicioso, prohibido, desordenado, o indecente". ${ }^{.6}$

Y en el tomo II de sus Cartas eruditas, volviendo al tema de los supuestos milagros, recupera la célebre tríada de Plutarco, luego elaborada por santo Tomás:

"La sagrada virtud de la Religión, conducida en la Nave de la Iglesia, navega entre dos escollos opuestos: uno es de la impiedad, otro el de la superstición. En cualquiera de los dos que tropiece, padecerá funestísimo naufragio. Así es menester llevar la Religión por un medio igualmente distante de uno, y otro".67

64 1739. Diccionario de la lengua castellana, en que se explica el verdadero sentido de las voces, su naturaleza y calidad: t. VI, 187. Madrid: Por los herederos de Francisco del Hierro.

65 Fr. Benito Feijoo y Montenegro, Theatro Crítico Universal, en 8 volúmenes publicados entre 1726 y 1739 . Aquí se ha utilizado la ed. de 1778. Madrid: Por D. Joachín Ibarra. Véanse sobre todo el t. I, discurso XIV: "Música de los templos"; t. III, discurso VI: "Supuestos milagros"; t. V, discurso XVI: "Tradiciones populares"; y t. VII, discurso VIII: "Toro de San Marcos".

66 Feijoo, B. 1778: t. VII, 220.

67 Feijoo, B. Cartas eruditas y curiosas, 5 volúmenes publicados entre 1742 y 1760 . He utilizado las ed. de 1773 y 1777 . Véase aquí el t. II, 1773: 143-144. 
A Feijoo le preocupaba poco la impiedad y bastante más la superstición, pues ésta se alimentaba de la ignorancia del vulgo, del que no tenía buena opinión. Son continuas sus referencias a "la plebe supersticiosa", "el estúpido vulgo", "la necedad del vulgo" o "la turba ignorante". 68 Precisamente el discurso I del Teatro Crítico va dirigido a impugnar "aquella mal entendida máxima de que Dios se explica en la voz del pueblo" y a defender una idea que hoy no puede ser más políticamente incorrecta: "el valor de las opiniones se ha de computar por el peso, no por el número de las almas. Los ignorantes, por ser muchos, no dejan de ser ignorantes"; y en el tomo III, hablando de la credulidad milagrera abunda en su desconfianza hacia el pueblo:

"Para admitir qualquier error el vulgo es sumamente fácil; pero para dexarle, sumamente indócil. Es de cera para la mentira, y de bronce para el desengaño. Sigue el partido de sus aprehensiones contra el informe de sus propios sentidos; o en sus propios sentidos la más ruda perspectiva pasa por perfecta realidad". ${ }^{69}$

De ahí que la Religión, "concretada al vulgo", "nada, o casi nada peligra hacia el primer escollo (la impiedad), y al contrario peligra infinito hacia el segundo". El pueblo es tan inclinado a toda clase de supersticiones que necesita una "extrema vigilancia" por parte de los que rigen la nave. Entre ellas, no es la idolatría la que más le preocupa, aunque es consciente de que "los Hereges, para cuyos ojos lo negro es blanco, y lo blanco negro, nos colocan entre los Idólatras". Feijoo lo tiene claro desde la más estricta ortodoxia: "Si la adoración de la Imagen es ordenada a la Deidad verdadera, como se practica entre los Cathólicos, es culto religioso". ${ }^{70}$ Por el contrario, se impone la tarea de fustigar las vanas observancias, las dudosas reliquias, los falsos milagros, los fraudes astrológicos y adivinatorios, las fábulas de duendes, saludadores y exorcistas, las supersticiosas creencias en la campana de Velilla o en el toro de San Marcos.

Ahora bien, pese a su desconfianza en el vulgo, Feijoo no elude la crítica a otros responsables de que las supersticiones se mantengan, y ello dará pie a un sustancioso debate en las siguientes décadas:

"Uno, el que algunos de los mismos, que pudieran, y debieran desengañar al Pueblo, le fomentan (ellos saben el motivo) en su vana creencia. Otro, que los que dotados de mejores luces conocen quánto importa depurar de vanas credulidades, que son como lunares suyos, la hermosura de la Religión, rara vez se atreven a oponerse a los caprichos del ciego vulgo, que protegidos de algunos, que no parecen vulgo, no duda de insultarlos como poco afectos a la Católica piedad, o tibios en la Fe".71

\footnotetext{
68 Tomo estas expresiones del t. V, discurso XVI: “Tradiciones populares": 350-354.

69 Feijoo, B. 1778: t. I, discurso I, 1: "Voz de el pueblo"; y t. III, discurso VI, 130: "Supuestos milagros". Y en el t. V, al tratar las tradiciones populares: "Es ídolo del vulgo el error hereditario. Qualquiera que pretende derribarle, incurre, sobre el odio público, la nota de sacrílego" (354).

70 Feijoo, B. 1783, Adiciones a las obras...: 1-6, "Sobre la recta devoción, y adoración de las imágenes".

71 Feijoo, B. 1777. Cartas eruditas: t. II, 144, "Examen de milagros".
}

El párrafo está lleno de vaguedades o, si se quiere, de sobrentendidos. ¿Quiénes son "algunos"? ¿Los frailes y clérigos? ¿Los ministros de la monarquía? ¿Los que se oponen a las Luces? Y, sobre todo, ¿cuál es el motivo que "ellos saben"? ¿Mera pusilanimidad? ¿Uso de la superstición para mejor dominar al pueblo? ¿Defensa de intereses espurios? Todas estas cuestiones están latentes, de un modo u otro, en el debate posterior y se responde a ellas de formas distintas, según sea la perspectiva desde la que se aborda el problema. Veamos cómo entendieron la superstición los que favorecieron la llustración dentro de unos límites, los que se opusieron a ella, y los contestatarios que pretendieron ir más allá de esa raya roja fijada en la fe católica y en las estructuras económico-sociales del Antiguo Régimen.

Sabido es que Menéndez Pelayo vio en nuestro siglo XVIII una "lucha feroz, ordenada, regular e implacable que los consejeros de Carlos III y de Carlos IV, los Aranda, Rodas, Moñinos, Campomanes y Urquijos emprendieron contra la Iglesia en su cabeza y en sus miembros". Aranda era, en su opinión, un impío, y una evidencia incontestable de ello los elogios que le dedicara Voltaire. En cuanto a los demás, "bien dijo Pío VI que los ministros de Carlos III eran hombres sin religión. Aquel monarca, piadoso, pero cortísimo de alcances (...) estaba literalmente secuestrado por la pandilla de Aranda y Roda, que Voltaire Ilamaba coetus selectus".72 Hoy sabemos que no debe confundirse el regalismo con la irreligión, y que la mayor parte de los ilustrados españoles eran devotos creyentes, si bien cada vez más alejados de la religiosidad popular, que veían plagada de supersticiones, muy en la línea, pues, de Feijoo y de las apreciaciones de muchos viajeros. Teófanes Egido ha caracterizado las actitudes religiosas de los ilustrados señalando que "evangelismo y cristocentrismo suponen reasumir el modelo humanista y 'erasmiano', la negación radical de las formas barrocas y el intento de imponer una religión menos expresiva y más interior", despojada de la muchedumbre de mediaciones que para ellos eran "vestigios de paganismo y expresiones de crasa superstición". ${ }^{73}$

$Y$ esto mismo fue lo que los reformistas ilustrados trataron de hacer desde el poder. De lo que entendían por supersticiones que había que erradicar da una buena idea, por ejemplo, la Instrucción reservada que la Junta de Estado, por orden de José Moñino, conde de Floridablanca, publicó

\footnotetext{
72 Menéndez Pelayo, M. 1987: t. II, 487 y 490.

33 Egido, T. 1988: 230. Para comprender la brecha abierta entre los ilustrados y las creencias populares, nada mejor que la anécdota relatada por Giacomo Casanova en que da cuenta de la conversación entre un mozo de mulas y un cura ilustrado: "Nada era más divertido que oírle hablar de religión con el cura; uno y otro eran muy devotos y probablemente muy ortodoxos en la intención; pero el caso es que existían diferencias radicales entre las dos creencias. Como la mayor parte de los eclesiásticos, todos los homenajes y todas las adoraciones del cura joven eran para Nuestro Señor Jesucristo; apenas si mencionaba a Dios Padre. El mozo de mulas, al contrario, no hablaba de ellos, como si no existiesen; todas sus oraciones eran para la Virgen... Mi mulero, aragonés, defendía a la Virgen del Pilar; oyéndole, valía más que todas las demás juntas" (Cit. García Mercadal, J. 1999: t. V, 147). Sobre este tema véase también el artículo de Pereira Pereira, J. 1988. "La religiosidad y la sociabilidad popular como aspectos del conflicto social en el Madrid de la segunda mitad del siglo XVIII", en Equipo Madrid. 1988. Carlos III, Madrid y la llustración: 223-254. Madrid: Siglo XxI.
} 
en 8 de julio de 1787. En ella se instaba al clero y a sus prelados "a desterrar supersticiones, y promover la sólida y verdadera piedad, que consiste en el amor y caridad con Dios y con los prójimos". Una vuelta a la oposición ciceroniana entre las nocivas supersticiones y la religión que encarna las virtudes cívicas, pues se entiende que las primeras mantienen "la ociosidad, los vicios y los gastos, y perjudican al verdadero culto y al socorro de los pobres". De ahí que, entre otras medidas, fuera bueno disminuir o extinguir las cofradías, para obviar "las distracciones y fiestas profanas y tal vez pecaminosas", sin olvidar los "gastos de comidas, refrescos y pompas vanas y gravosas a mis vasallos". Y Floridablanca terminaba recordando que la Inquisición, en cuanto persecutora de la herejía, la apostasía y la superstición, debería colaborar a este mismo fin, el de instruir a los pueblos en la verdad o, lo que es lo mismo, "hacer que sepan separar la semilla de la zizaña (sic), esto es, la religión de la superstición". ${ }^{74}$

Un caso especialmente significativo, dado su predicamento entre los grupos ilustrados, es el de Gaspar Melchor de Jovellanos, devoto católico y contrario a los experimentos revolucionarios, pero defensor de posiciones avanzadas en algunas cuestiones importantes, tal que la ley agraria. Como "ente religioso", pues lo es el hombre por naturaleza, el asturiano se esforzó por mantenerse en un centro equidistante de la impiedad y de la superstición, a la que describe en términos muy duros:

"Sometiendo de una parte los hombres a vanas y ridículas creencias, y a horribles ilusiones y temores, y de otra multiplicando sus leyes morales y rituales, y las reglas de su conducta religiosa y civil, degrada a un mismo tiempo el augusto carácter de la divinidad y la dignidad de la especie humana, robando a sus individuos hasta la escasa porción de felicidad que pudieran gozar en la tierra. Hija de la ignorancia es madre del fanatismo, si acaso el fanatismo no es la misma superstición puesta en ejercicio, y arrojada por otro derrumbadero a los mismos males que produce la impiedad". ${ }^{75}$

La superstición, como la entiende Jovellanos, es un vestigio del pasado, de los tiempos oscuros y bárbaros, que al parecer sitúa en la Edad Media. España "tardó algunos siglos en salir de este abismo", rayó el siglo Xvı cuando la soberanía recobró su autoridad, hubo un nuevo retroceso $y$, al fin, "del seno mismo de la ignorancia y el desorden nació el estudio de la economía civil". Los borbones, Felipe y Fernando, desbrozaron el camino hasta llegar a Carlos III:

"Determinado este piadoso soberano a dar entrada a la luz en sus dominios, empieza removiendo los estorbos que podían detener sus progresos. Éste fue su primer cuidado. La ignorancia defiende todavía sus trincheras, pero Carlos acabará de derribarlas. La verdad lidia a su lado, y a su vista desaparecerán del todo las tinieblas". ${ }^{76}$

74 Floridablanca (Moñino y Redondo, J.). 1867. Obras originales del Conde de Floridablanca y escritos referentes a su persona: 217. Madrid: M. Rivadeneira Impresor.

75 Jovellanos, G.M. de. 1831. Tratado teórico-práctico de enseñanza pública: 136-138. Madrid: Imprenta de D. León Amarita.

76 Jovellanos, G.M. de. 1858-59. Elogio de Carlos III, en Obras publicadas e inéditas: t. I, 312-313. Madrid: M. Rivadeneira Impresor. Véase también la carta a Antonio Ponz: "Sobre el origen y costumbres de los vaqueros de alzada en Asturias" (1858-59: t. II, 304-305).
Literatura áulica, sin duda, pero puede que bastante sincera si consideramos que semejantes expresiones de fe en el progreso y en la fuerza regeneradora de la ilustración no son raras en sus escritos más íntimos. Así, en sus diarios, después de desahogarse contra el inquisidor, "el tonto del cardenal Lorenzana", por haberle negado la licencia para tener libros prohibidos en la biblioteca de su instituto gijonés, escribe: “¿Qué dirá de él la generación que nos aguarda y que a pesar del despotismo y la ignorancia que la oprimen será más ilustrada, más libre y feliz que la presente? ¿Qué barreras podrán borrar las avenidas de la luz y la ilustración?".77

Al contrario que otros ilustrados y ministros de su generación, preocupados, con su rey a la cabeza, por las amenazas que provienen del vulgo, Jovellanos no reprueba las diversiones populares y critica con dureza la política represora llevada a cabo con harto despotismo:

\begin{abstract}
"En unas partes se prohíben las músicas y cencerradas, y en otras las veladas y bailes. En unas se obliga a los vecinos a encerrarse en sus casas a la queda, y en otras a no salir a la calle sin luz, a no pararse en las esquinas, a no juntarse en corrillos (...) y el infeliz gañán, que ha sudado sobre los terrones del campo y dormido en la era toda la semana, no puede en la noche del sábado gritar libremente en la plaza de su lugar, ni entonar un romance a la puerta de su novia". ${ }^{78}$
\end{abstract}

En efecto, el pueblo necesita diversiones, no espectáculos; necesita divertirse, no que lo diviertan. Si no es partidario de las fiestas de toros ni del teatro tradicional, Jovellanos no oculta su entusiasmo cuando, en una de sus cartas a Antonio Ponz, describe las romerías asturianas, "las únicas diversiones que conoce el pueblo de este país". ${ }^{79}$ Ello no le impide, sin embargo, criticar con acritud los excesos con que la ignorancia contamina la pureza de la religión. Así, esta burla de las rogativas frailunas: "Agua abundante toda la mañana, con general alegría. ¡Vivan los clérigos! Machacón dice que la arrancaron sus voces. En efecto, anoche ponía sus berridos en el cielo". O su enorme disgusto por la ridícula escenografía con que se presentaba a los fieles el Santo Cristo de Burgos en el convento de agustinos, "aparatos bien inventados para provocar la devoción del vulgo", con proliferación, "dentro y fuera de la capilla, y por todo el claustro, de carros de muletas, de piernas y brazos, y tetas de cera, y aún de plata, votos, testimonios de estupidísima superstición". ${ }^{80}$

En su paisano y protector Campomanes encontramos menos matices. En 1750, en plena juventud, escribe a

\footnotetext{
77 Jovellanos, G.M. de. 1956. Diarios, en Obras: 316-317. Madrid:

78 Jovellanos, G.M. de. 1998. Memoria sobre espectáculos y diversiones públicas: 185 . Madrid: Cátedra.

79 Jovellanos, G.M. de. 1976, Obras en prosa: 143 y ss. Madrid: Castalia. "¡Ojalá pudiese inspirarle también una parte de aquellas deliciosas sensaciones, que tantas veces excitó en mi alma el espectáculo de la inocencia pura y sencilla, entregada al esparcimiento y alegría! Espectáculo tanto más digno de la atención de la filosofía, cuanto más relación tiene con el interés general de estos pueblos, y cuanto más influye en la felicidad personal de sus individuos" (ibídem, 144).

80 Jovellanos, G.M. de. 1956. Diarios: t. LXXXV, 320 y 256 respectivamente.
} Atlas. 
Feijoo contra las desviaciones del "torpe vulgo", en que incluye las mayas, las enramadas de San Juan, las zambombas de Nochebuena, los carnavales, los judas de San José, las cruces de mayo, las procesiones irrespetuosas del Corpus y sus gigantones, y otras demostraciones de la cultura popular que inducían al pueblo a la superstición. ${ }^{81}$ Otros autores de la generación de Jovellanos dirigen sus críticas hacia los desvaríos que observan en las procesiones. Moratín, en sus comentarios satíricos al Auto de Fe de Logroño de 1610, se burla de la "doctrina frailesca" que induce a adorar las imágenes de la Virgen por encima de las del mismo Jesucristo en las procesiones de Semana Santa; ${ }^{22}$ y el fiscal Meléndez Valdés, "con motivo de las griterías y alborotos del pueblo en los días de Jueves y Viernes Santo", previene contra las procesiones sacramentales a las que concurre un gentío inmenso, "excitado, más que de devoción, de la curiosidad, la vanidad, el ocio". Las procesiones son, a su juicio,

"obras todas ellas del lujo y la profusión, contrarias las más a la pura y sana disciplina, nacidas por lo común en la Edad Media, y efecto de su ignorancia crasa y sus tinieblas, y causa necesaria de irreverencias y desacatos, de gastos indebidos, de borracheras y desórdenes, de corrupción en las costumbres públicas, de temores y riesgo para la seguridad". ${ }^{83}$

Nada más ajeno de la religión, "cuyo culto debe ser todo en espíritu y verdad", que "esas galas y profusión de trages", "esas imágenes y pasos llevados por ganapanes alquilados", "esas hileras de hombres distraídos", "esos balcones llenos de gentes apiñadas", esos convites, ese bullicio, "esa liviandad y desenvoltura de las mugeres" y, en fin, "ese todo de cosas estravagantes que se ven en una procesión". En consecuencia, propone suprimirlas "o reducirlas a lo menos a lo que deben ser según el espíritu de nuestra santa religión y el loable objeto que pudieron tener en sus principios". ${ }^{84}$

\section{LA CRUZADA CONTRA LA IMPIEDAD}

El verdadero enemigo de los adversarios de la llustración no fue la superstición, sino la impiedad, que por medio de la pluma de los filósofos amenazaba los fundamentos mismos de la religión. Menéndez Pelayo incluye entre lo que llama "impugnadores del enciclopedismo" a autores como Ceballos, Forner y fray Diego José de Cádiz, entre otros. ${ }^{85}$ Fernando de Zeballos y Mier escribió una voluminosa obra en seis volúmenes, por demás inacabada, con el título de La falsa filosofía, que don Marcelino consideraba, de haber

81 Egido, T. 1988: 226.

82 Fernández de Moratín, L. 1850. En Obras de D. Nicolás y D. Leandro Fernández de Moratín: 620. Madrid: M. Rivadeneira Impresor.

83 Meléndez Valdés, J. 1821. Discursos forenses: 192-193.

84 Meléndez Valdés, J. 1821. Discursos forenses: 193-194. Madrid: En la Imprenta Nacional. Critica asimismo el lujo escandaloso "que provoca a la miseria pública, cuando mil infelices gimen consumidos del hambre y de la desnudez" (ibídem, 195).

85 Menéndez Pelayo, M. 1987: t. II, 580. No sorprende que también incluya a Olavide, pues es autor de El Evangelio en triumpho, o Historia de un filósofo convertido (Valencia, 1797), pero sí, y mucho, Jovellanos, aún a pesar de su moderantismo en cuestiones de religión. sido concluida, una antienciclopedia. ${ }^{86}$ El autor arremete contra los impíos que confunden la llustración con su falsa filosofía, o sea, el ateísmo, el deísmo y otras nuevas sectas; y que, por contra, denigran a la religión acusándola del exceso contrario: "Superstición, así llaman a la Religión Católica los impíos". ${ }^{87}$ En el tomo IV retoma la vieja cuestión planteada por Plutarco y posteriormente rescatada por Voltaire: la de qué es peor, la superstición o la impiedad. La respuesta es coincidente con la de Voltaire, pero por razones completamente diferentes. Cierto que en la Escritura una de las supersticiones, la idolatría, fue considerada el pecado máximo; pero, con todo, es el ateísmo, "colmo de la impiedad", "el mayor crimen, considerado en sí mismo". Si el principio del mal es la superstición, la impiedad o ateísmo sería su fin y complemento, el mal absoluto, perniciosísimo para los estados. La superstición, en efecto, supone leyes malas y torpes, pero en el ateísmo desaparece toda ley. Todos necesitan de una religión, por muy penetrada que esté por la superstición. ${ }^{88}$

Los filósofos son también el blanco de los ataques de Juan Pablo Forner, uno de los apologistas que contestaron el artículo de la Encyclopedie Méthodique. ${ }^{89}$ En sus Discursos filosóficos sobre el hombre, se refiere a aquéllos como "una caterva de Don Quijotes de Filosofía que desprecian todas las religiones del mundo". De creerlos a ellos, "todo es superstición, todo sagacidad humana para contener a los hombres en su esclavitud". Forner es, con todo, un racionalista que ha leído a Voltaire y a los philosophes, pero que desconfía de la mera Razón, a la que considera "asilo de la impiedad". "La verdadera Filosofía -escribe- no sólo no se opone, sino antes bien favorece a la Religión, y prueba invenciblemente la necesidad de que la haya y de que sea sola una en la tierra"..$^{90}$ En defensa de la necesaria religión escribió, incluso, un Preservativo contra el ateísmo, en donde prueba que sin religión no puede haber un gobierno justo, y ni siquiera es posible la sociedad. La religión, en cuanto freno a la libertad desbocada del hombre, es el fundamento de la sociedad humana. Forner reconoce que "una religión que conste sólo de ceremonias y cuya virtud consista únicamente en las libaciones, lustraciones, genuflexiones, etc., no sólo será inútil; pero, lo que es peor, degenerará en superstición monstruosa y ridícula, indigna de la majestad del objeto, e injuriosa a la racionalidad". Pero es que la superstición, tal como él la entiende, ya no está en

86 Ceballos, F. de. 1774-76. La falsa filosofía, o el ateísmo, deísmo, materialismo, y demás sectas nuevas... Madrid: En la Imprenta de D. Antonio Sancha, en 6 volúmenes. Menéndez Pelayo dice de este autor: "Su vida fue una continua y laboriosa cruzada contra el enciclopedismo en todas sus fases, bajo todas sus máscaras, así en sus principios como en sus más remotas derivaciones y consecuencias sociales, que él vio con claridad semiprofética y denunció con generoso brío, sin que le arredrasen prohibiciones y censuras laicas ni destierros y atropellos cesaristas" (1987: t. II, 586).

87 Ceballos, F. de. 1774: t. I, dedicatoria a Campomanes fechada en 8 de octubre de 1773 . El comentario sobre la superstición puede verse en el "Índice de las cosas más notables".

88 Ceballos, F. de. 1775: t. IV, 4-20; t. VI, 103.

89 Forner, J.P. 1976. Oración apologética por la España y su mérito literario. Madrid: Doncel.

90 Forner, J.P. 1787. Discursos filosóficos sobre el hombre. Madrid: Imprenta Real. 
el extremo opuesto. El verdadero combate se libra entre la religión y la impiedad.

"El ateísmo y la religión son dos términos contradictorios, y en la inmensa distancia que los divide caben infinitos grados o clases de superstición... y así, por grados sucesivos, inferiremos que cuanto más las supersticiones se vayan alejando de la perfecta religión y acercándose al ateísmo, irá menguando el influjo de aquélla y creciendo el de éste".

La religión ya no está en el término medio, donde la colocara Plutarco; es el bien absoluto, el orden. En la superstición, que se interpone entre ambos contendientes, podrá haber mayor o menor desorden, "según se acerque más o menos a la impiedad". Y esta última ocupa el extremo opuesto: es el caos. "El ateísmo es una ponzoña que lleva irremediablemente a la muerte" al cuerpo político y social. ${ }^{91}$

Cuando Forner dio a la imprenta su Preservativo había estallado ya la guerra contra la Francia revolucionaria. Con este motivo publicó el famoso predicador fray Diego José de Cádiz una soflama bajo el título de El Soldado Católico en guerra de religión. La espada militar era el instrumento escogido por Dios para castigar los crímenes más execrables, que por supuesto eran la impiedad, la irreligión y la apostasía, encarnadas no ya en la filosofía, sino en su monstruosa consecuencia, la Convención de Francia, que no admitía divinidad alguna, prohibía el culto exterior, despreciaba las Sagradas Escrituras, se mofaba de la Revelación, se reía de la infalibilidad del dogma y, en definitiva, perseguía a la Iglesia y abominaba de sus ritos. La lucha contra la irreligión era, pues, una verdadera cruzada; $y$, en esta creencia, arengaba a su sobrino, que se había enrolado como voluntario:

"Esfuérzate, cobra ánimo, depón todo temor, y puesto en Dios tu amor y tu esperanza, desenvaina tu espada y santifica tus manos, consagrándolas con la sangre y con la muerte de los enemigos de Dios y de su Iglesia".92

Desde las posiciones tradicionalistas, la cuestión de la superstición se diluye en aras del combate contra el verdadero enemigo, la impiedad o el ateísmo. No obstante, pueden encontrarse algunos tratados que no sólo la toman en consideración, sino que descienden a lo concreto y se comprometen a trazar la sinuosa línea que separa a la religión de la superstición. Así lo hace el jesuita Pedro de Calatayud, que hubo de bregar, en sus frecuentes misiones, con los problemas más prácticos de la religiosidad. En la segunda parte de sus Opúsculos trató extensamente acerca de la superstición, una falsa religión o "culto vicioso, y opuesto, o en quanto al objeto, o en quanto al modo, al culto verdadero, y proprio de la Religión". El jesuita toma de santo Tomás las dos especies de superstición: por un lado, el culto que se rinde al diablo y que da lugar a la idolatría, la adivinación,

91 Forner, J.P. 1795. Preservativo contra el ateísmo. Sevilla: Félix de la Puerta.

92 Fray Diego José de Cádiz, 1814. El Soldado Católico en guerra de religión (1794): Parte I, 28 y 34; Parte II, 13 y 75. La obra está fechada en Sevilla, el 8 de diciembre de 1793. la magia y la vana observancia, a las que dedica numerosas páginas; por otro, el culto que se ofrece al verdadero Dios, pero de un modo indebido, es decir, "irreverente, superfluo, falso, pernicioso, o contra los ritos y méthodo que observa la Santa Iglesia". ${ }^{93}$ Pero lo interesante de la propuesta de Calatayud es que va mucho más allá de esta esquemática clasificación, señalando hasta nueve casos en que se traspasa la raya y se cae en el pecado de superstición. Son éstos:

1. Los que se valen de ritos y ceremonias del judaísmo, o de moros o herejes.

2. Los que engañan con falsas reliquias.

3. Los que fingen milagros, como que tal imagen sudó, a fin de sacar limosnas.

4. Los que utilizan imágenes indecentes que despiertan feos pensamientos.

5. "Los que en los Maytines de la noche de la Natividad del Señor mezclan al tiempo de leer las Lecciones, saynetes, apodos, palabras, y expressiones indecorosas, torpes, y gravemente disonantes de aquel paso, y sagrado mysterio, por el grave escándalo que dan en esto". ${ }^{94}$

6. Los que ofrecen un don en acción de gracias por haber logrado algún fin torpe.

7. Los que ayunan públicamente en los domingos y los que se disciplinan públicamente en las procesiones del día de Resurrección. ${ }^{95}$

8. Las cofradías que festejan a un santo con comedias torpes y convites excesivos.

9. Los que tratan de conseguir de Dios alguna cosa por medio de ceremonias inútiles: con un determinado número de luces, en tal altar o haciendo tal devoción para librarse del purgatorio o para morir en gracia, decir la oración de San Cipriano para preservarse del mal, orar en la noche de San Juan para saber con quién se ha de casar, llevar partes del ara o corporales con pretensiones vanas, etc.

De igual forma, el jesuita excluye de la superstición otras devociones polémicas, en algunos casos en franco desacuerdo con las opiniones de Feijoo. Así, formarían parte del culto legítimo:

1. Que los labradores den vueltas con sus bestias alrededor de la ermita, el día de San Antonio Abad.

2. Conjurar el día de San Marcos un toro bravo para que participe mansamente en la procesión y los oficios divinos.

93 Pedro de Calatayud, 1754. Opúsculos y doctrinas prácticas: t. III, 191-192. Logroño: En la Imprenta de Francisco Delgado.

94 Ibidem, t. III, 192. Aunque esto no sea especie de superstición, "es grave pecado de sacrilegio, y que prohíbe el Concilio Tridentino, Sessione 4, el traher los textos de la Sagrada Escritura para usos profanos, para pasquines, libelos infamatorios, sátyras, o papeles, en que se celebran las intenciones dañadas, vicios, o fines torcidos de Príncipes, Personages, Prelados, Cabezas seculares, Religiosos y otras personas". Y concluye: "Las cosas Santas se han de tratar santa, y no profana, o livianamente". Y en el índice: "Natividad del Señor: es ofensiva al Dios de la Magestad la bulla, e indecencia, que tal vez se practica con cazos, sartenes, y ruidos al oído de quien celebra en aquella noche".

95 Nótese que no se trata de una proscripción de los flagelantes, que considera lícitos en las procesiones de Jueves y Viernes Santo. 
3. Llevar un caballo aderezado en la procesión del Corpus.

4. Predecir el tiempo a partir del comportamiento de los animales. ${ }^{96}$

Si se contrapone la doctrina del padre Calatayud con la de Feijoo la línea que separa a la religión de la superstición se antoja, de nuevo, sumamente equívoca y sinuosa.

\section{EL COMBATE CONTRA LA SUPERSTICIÓN}

El ala izquierda de la ilustración no es el antro de la impiedad que supusieron los reaccionarios y menendezpelayistas. Los ilustrados más radicales, precursores en muchos aspectos del liberalismo, ${ }^{97}$ partieron de los mismos planteamientos clásicos y cristianos, si bien llegaron a conclusiones opuestas o se atrevieron a realizar críticas más audaces. Así, en las páginas de El Censor se publicó un discurso, con fecha de 20 de diciembre de 1781, que sostenía "Que la superstición está entre nosotros más extendida que la impiedad":

"La superstición es un delito contra la religión igualmente que la incredulidad, un vicio que, reduciéndola a meras exterioridades y apariencias, la enerva, la destruye y la aniquila, con tanta más facilidad cuanto hiere más la imaginación, tiene un acceso más fácil en los ánimos y un apoyo más seguro en la ignorancia y en la propensión de los más en los hombres a lo maravilloso". ${ }^{98}$

El periódico pone en evidencia la idolatría del culto a los santos, que son igualados al mismo Dios, o de la desmedida veneración de las imágenes. “iCuánto se mezcla de idolatría en esta mayor devoción a la Divina Pastora que a la Peregrina, o a la Peregrina, que a la de la Leche!". El culto está lleno de ceremonias vanas y superfluas; las oraciones, de necedades y blasfemias; por todas partes se pretende celebrar las fiestas de Dios y de sus santos con romerías, bailes impuros, comilonas y borracheras; la música teatral irrumpe en los oficios divinos y lo sagrado se contamina de profanidad. Y, sin embargo, en los sermones se critica la impiedad y no se tiene en cuenta a la superstición, que es más dañina. Los supersticiosos, a diferencia de los impíos, se hallan por todas partes. Pero no se trata sólo de la ignorancia del vulgo, sino de algo mucho más preocupante, que es lo que aleja esta denuncia de la ilustración bienpensante y moderada:

"Hay otro vulgo que comprende un sin número de mercedes y muchas señorías de pelo entero, muchas excelencias, y aún también otros tratamientos que no parecía posible comprendiese, en el cual se hallan otras infinitas

96 "al ver por las paredes las arañas, al bañarse en tiempo de sequedad las palomas, y páxaros en las pilas de agua, al bramar los bueyes, y becerros, al cantar tal ave, al correr, y chillar los ratones", todo lo cual se conjetura por causas naturales, "y consta por la experiencia". Ibidem, t. III, 194.

97 Elorza, A. 1970. La ideología liberal en la Ilustración española. Madrid: Tecnos.

${ }_{98}$ El Censor (1781-1789). 2005: 132. Barcelona: Crítica. Ed. de F. Uzcanga. supersticiones, de las cuales, si bien algunas necesitan de una observación atenta, no por eso dejan de serlo". ${ }^{99}$

La superstición, pues, no es exclusiva del pueblo atrasado; hay otra que se sustenta en los intereses de los nobles y privilegiados. Cabría la tentación de secularizarla y entenderla en términos políticos y sociales. La lucha contra esta superstición implicaría, pues, cambios profundos en el viejo régimen. Es lo que sostendrá, una década más tarde, José Marchena al defender, en su proclama "A la Nación española", esa "revolución sublime" que "ha derribado de su trono de oro la superstición y la tiranía para colocar sobre él la igualdad y la razón". ${ }^{100}$ No por su extremismo político renuncia Marchena a la pureza de sus creencias, que están "tan lejos de la irreligión y la impiedad, como de la superstición y el fanatismo":

"Sí, señor, soy cristiano; me glorío de serlo, y lo soy por convencimiento y persuasión... Esta confesión que hago con toda sinceridad es de tanto más peso, cuanto que he leído todos los argumentos de los irreligiosos (...) Pero si venero con escrúpulo la religión, desprecio altamente todas las supersticiones que pasan por artículos de ella, y que el estudio raciocinado de la Escritura y la Historia Eclesiástica me ha enseñado a discurrir". ${ }^{101}$

Las críticas más acerbas a una religión poseída de supersticiones y vanas ceremonias se encuentran en los escritos de León de Arroyal. En la cuarta de sus Cartas económicopolíticas contrapone la cura de almas, verdadera finalidad de la sana religión, al vacío ritual que consiste en "destripar antífonas ante un terrible facistol" y "Ilenar las catedrales de capones y flautistas, más propios del teatro de Atenas que del templo de Jerusalén". Su crítica de la superfluidad de la liturgia resulta demoledora:

\footnotetext{
"¿De qué sirven a los fieles estas opulentas catedrales que parecen solamente destinadas a dar ejercicio al pulmón y mantener en una santa ociosidad, aislados en medio de la diócesis, a una gran parte del clero? Dígaseme a qué ministerios eclesiásticos están adscritos sus individuos, si no es al coro. Ellos no tienen por instinto el bautizar, el predicar, el confesar, el administrar, el ayudar a bien morir, el casar, el enterrar, el enseñar, en fin, ninguno sino el cantar, y aún éste le dejan a los salmistas y gente de gradas abajo; mas, con todo, ellos tiran de la mayor parte de los diezmos". ${ }^{102}$
}

Los cabildos, denuncia el autor, son como las maestranzas, "que todas sus actas se reducen a fiestas"; y sólo "desterrar del culto cuanto huela a profano" conservará a la religión en toda su pureza.

Aún más incisivo se muestra Arroyal en el panfleto Pan $y$ toros, en el que describe a una España profundamente

99 Ibidem, 132-136.

100 Marchena, J. 2010. Improvisación de un español, admitido por aclamación y con unanimidad, en el Club de los Amigos de la Constitución de Bayona (1792), en Pan y toros y otros papeles sediciosos del siglo XVIII: 24. Madrid: La Piqueta.

101 Marchena, J. 1990. Obra española en prosa: 85 y 90. Madrid: Centro de Estudios Constitucionales.

102 Arroyal, L. de. 1971. Cartas económico-políticas: 91-92 y 101102. Oviedo: Universidad de Oviedo. 
supersticiosa en su decrepitud. En ella hay más templos que casas, más sacerdotes que seglares, más aras que cocinas.

"No se da paso que no se encuentre una cofradía, una procesión o un rosario cantado, por todas partes resuenan los chillidos de los capones, los rebuznos de los sochantres y la algarabía sagrada de los músicos, entreteniendo las almas devotas con villancicos, gozos y arietas de una composición tan seria y unos conceptos tan elevados, que sin entenderlos nadie hacen reír a todos; hasta los más recónditos y venerables misterios de la religión se cantan por los ciegos a las puertas de los bodegones al agradable y majestuoso compás de la guitarra. No hay esquinazo que no se empapele con noticias de novenarios, ni en que dejen de venderse relaciones de milagros tan creíbles como las transformaciones de Ovidio". ${ }^{103}$

Protegido en su anonimato, el autor no deja títere con cabeza en esta España "vieja y regañona, brotando leyes por todas las coyunturas", una España "decrépita y supersticiosa que pretende encadenar hasta las almas y los entendimientos". El "influjo frailesco" ha desfigurado el Evangelio, millares de "santurrones apócrifos" difunden patrañas ridículas y milagros increíbles; la Virgen de Atocha, la Almudena y la Soledad compiten "la primacía de milagrosas, y cada una tiene su partido de devotas, que, si no son idólatras, no les falta un dedo para serlo". La religión se ve reducida a meras exterioridades $y$, aunque cristianos en el nombre, somos peores que gentiles en nuestras costumbres. Pero los españoles, interesadamente mantenidos en la ignorancia y la degradación, viven contentos "con pan y toros", "satisfechos con su pobreza", e ignoran lo que es la libertad. Y Arroyal llega mucho más lejos que el más prejuiciado extranjero cuando presenta a España como "el non plus ultra del fanatismo de los siglos". ${ }^{104}$ Es una imagen que no puede menos que recordar las pinturas más negras de Goya, donde, en una orgía de violencia y de fanatismo, se desatan los monstruos surgidos del sueño de la razón. Pocas veces se ha representado de forma más expresiva la superstición como en el capricho no 52 ("Lo que puede un sastre"): un fantasmón oculto bajo un hábito frailuno, su rostro una calavera que apenas se intuye, sus brazos amenazantes convertidos en troncos arbóreos, se abate sobre un grupo de medrosas devotas que, de rodillas y con mirada suplicante, se entregan a su influjo, mientras el aire es surcado por brujas y figuras siniestras. La glosa manuscrita que acompaña al ejemplar de la Biblioteca Nacional de Madrid es casi tan expresivo como el propio aguafuerte:

"La superstición general hace que todo un pueblo se prosterne y adore con temor a un tronco cualquiera, vestido de santo". ${ }^{105}$

103 Arroyal, L. de. 2010. Pan y toros: 9.

104 He aquí el final del panfleto: "Desprecia como hasta aquí las hablillas de los extranjeros envidiosos, abomina sus máximas turbulentas; condena sus opiniones libres, prohíbe sus libros que no han pasado por la tabla santa y duerme descansada al agradable arrullo de los silbidos con que se mofan de ti. Haya pan y haya toros, y más que no haya otra cosa. Gobierno ilustrado, pan y toros pide el pueblo. Pan y toros es la comidilla de España. Pan y toros debes proporcionarle para hacer en lo demás cuanto se te antoje in secula seculorum" (ibídem, 21).

105 Capricho no 58: iLo que puede un sastre!, en Goya. Los Caprichos, 1994: 223. Véase sobre todo la versión acabada de la edición de 1799.

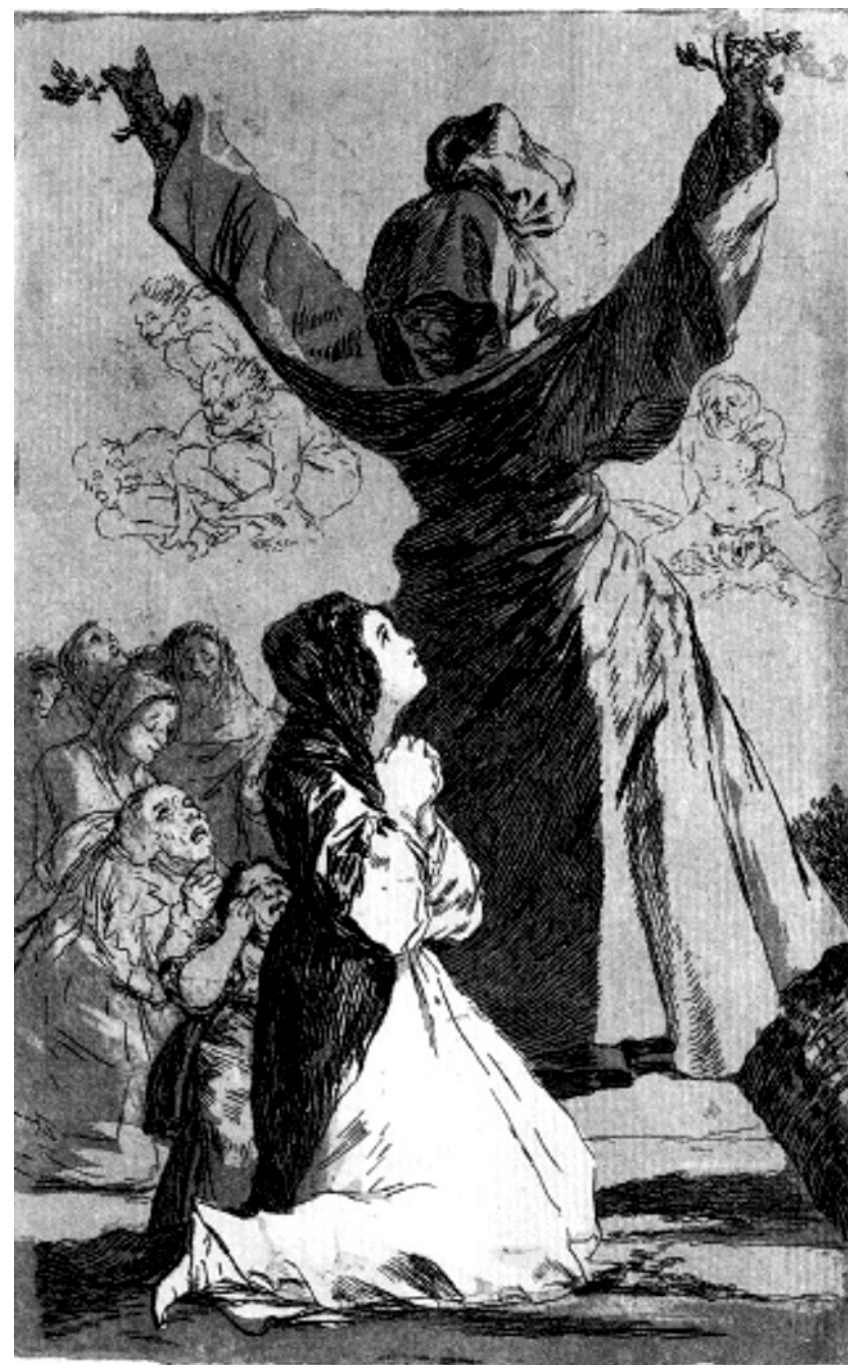

Francisco de Goya,

Capricho 52: "iLo que puede un sastre! Lámina de cobre 218×151 mm., edición 1799.

Calcografía Nacional. Madrid.

\section{CONCLUSIONES}

El absolutismo ilustrado, pese a las acusaciones de que ha sido objeto por parte de historiadores integristas, no fue en modo alguno enemigo de la religión, si bien la entendió a la manera humanista, cada vez más alejada de las sensibilidades barrocas. En consecuencia, no mostró un ápice de tolerancia respecto de la impiedad; y si reprimió la superstición, fue en su acepción más inofensiva, o sea, la que se adscribía a los errores y torpezas del vulgo, sin tocar las indudables supersticiones de los grupos dominantes, del poder o del propio orden establecido, como hubieran querido los ilustrados más osados.

El viejo teatro barroco fue el primero en sufrir la proscripción de los reformadores. Fernando VI prohibió la representación de comedias de santos, y en 1765 Carlos III la amplió a los autos sacramentales, "por ser los teatros lugares muy impropios y los comediantes instrumentos indignos

Madrid: Calcografía Nacional. 
y desproporcionados para representar los Sagrados misterios de que tratan". La orden volvió a ser confirmada en 1788 para incluir, junto a los autos y comedias de santos, a todas aquellas que versasen sobre magia, religión o incorporasen el personaje del demonio, pues "eran contrarias no sólo a las reglas más triviales y menos estrechas del teatro, sino también a la religión, a la razón, a las costumbres y a la decencia". ${ }^{106}$

En 1767 se vedó la impresión de pronósticos, romances de ciegos y coplas de ajusticiados, lo que es decir las principales manifestaciones de la literatura popular. En Madrid se pusieron fuera de la ley las cencerradas (1765), las mayas (1769), los juegos de azar (1771), la quema de los Judas en San José y el Sábado Santo (1772), el toque de instrumentos disarmónicos en las noches de San Juan y San Pedro (1772), y las tarascas y gigantones en la procesión del Corpus (1772). ${ }^{107}$ En 1777 una Real Cédula quiso terminar con uno de los principales blancos de la crítica extranjera, los disciplinantes, empalados "y otros Espectáculos en las Procesiones de Semana Santa", Cruz de Mayo y rogativas, incluidas las procesiones nocturnas, todo lo cual "no sirve de edificación, y pueden servir a la indevoción y al desorden". La prohibición alcanzó, además, los bailes ante las imágenes o en el interior de las iglesias, en sus atrios y cementerios. ${ }^{108} \mathrm{En}$ 1780 les llegó el turno a los gigantones y danzas del Corpus; en 1783 a los "saludadores, los que enseñan máquinas obscuras, marmotas, osos, caballos, perros y otros animales con algunas habilidades"; en 1785 se suprimieron las fiestas de toros que no se corriesen en plazas estables y, en fin, en 1787 , fueron proscritos los "insultos y obscenidades" que se proferían en las fiestas navideñas. ${ }^{109}$

De haber sido fundado el reproche de Ceballos ("Superstición, así llaman a la Religión Católica los impíos"), éstos, o sea, los filósofos, no se habrían contentado con menos que demoler la Iglesia entera para erradicar la superstición. Evidentemente, no fue el caso. Sobre lo que se discutía en realidad era por dónde pasaba la línea que separaba lo que se entendía por religión de lo que se tenía por superstición. Unos reducían ésta a unas pocas manifestaciones del vulgo; otros, extendían el término a la generalidad de las ceremonias externas, que la Iglesia reconocía o no en función de su mayor o menor control; unos terceros, en fin, confundían las supersticiones con el propio sistema y, en consecuencia, proponían cambios audaces. El reformismo del despotismo ilustrado, aun mostrándose radical

106 Cotarelo y Mori, E. 1997. Bibliografía sobre las controversias de la licitud del teatro antiguo español (1904): 657 y 682. Granada: Universidad de Granada.

107 Del Río, M.J. 1988: "Represión y control de fiestas y diversiones en el Madrid de Carlos III", en Equipo Madrid. Carlos III, Madrid y la Ilustración: 299. Madrid: Siglo XxI.

108 Real Cédula de S.M. y Señores del Consejo en que a consequencia de cierta Representación del Reverendo Obispo de Plasencia, se prohíben los Disciplinantes, etc. En Madrid, en la Imprenta de Pedro Marín, año 1777. Dada en El Pardo, a 20 de febrero de 1777. Asimismo se prohibió trabajar en público los días de fiesta.

109 Sánchez, S. 1794. Extracto puntual de todas las pragmáticas, cédulas, provisiones, circulares y autos acordados y otras providencias publicadas en el reynado del señor D. Carlos III. Madrid: En la Imprenta de la Viuda e Hijo de Marín. en su celo regalista, conservó una exquisita moderación equidistante, como la propia religión, de la impiedad por una parte, persiguiéndola con el concurso de la Inquisición, y por otra, de la superstición, entendida naturalmente como propia y exclusiva del vulgo, y a la que reprimió por medio de decretos prohibitivos, en los que el celo religioso se mezclaba con pragmatismos utilitarios y prevenciones de orden público.

\section{BiBLIOGRAFÍA}

Agustín de Hipona (San). La Ciudad de Dios, en Obras, ed. de F. Montes de Oca, disponible en http://efrueda.com/ wp-content/uploads/2011/12/L-a-ciudad-de-Dios.pdf, consultado el 11-01-2016.

Arroyal, León de. 1971. Cartas económico-políticas, ed. de J. Caso González. Universidad de Oviedo.

Bourgoing, Jean-François. 1789. Nouveau Voyage en Espagne, ou Tableau de l'état de cette Monarchie. París: Chez Regnault.

Bourgoing, Jean-François, 1803. Tableau de I'Espagne moderne. París: Chez Levrault frères.

Cádiz, (fray) Diego José de. 1814. El Soldado Católico en guerra de religión. Madrid: Imprenta de D. Francisco de la Parte.

Calatayud, Pedro de. 1754. Opúsculos y doctrinas prácticas, que para el gobierno interior, y dirección de las almas, y para el conocimiento, examen, y prueba de varios espíritus ofrece a sus directores, y confessores, y da a luz el Padre Pedro de Calatayud, de la Compañía de Jesús... Logroño: En la Impr. de Francisco Delgado, tomo III.

Caro Baroja, Julio. 1981. De la superstición al ateísmo. Meditaciones antropológicas. Madrid: Taurus.

Castañega, Martín de. 1994. Tratado de las supersticiones y hechizerías y de la possibilidad y remedios dellas (1529), ed. de J. R. Muro Abad. Logroño: Instituto de Estudios Riojanos.

Ceballos, Fernando de. 1774-76. La falsa filosofía, o el ateísmo, deísmo, materialismo, y demás sectas nuevas convencidas de crimen de estado contra los Soberanos, y sus Regalías, contra los Magistrados, y Potestades legítimas. Madrid: En la Imprenta de D. Antonio Sancha, 6 volúmenes.

Censor (EI). 2005. Ed. de F. Uzcanga. Barcelona: Crítica.

Cicerón, Marco Tulio. 1970. Sobre la naturaleza de los dioses, ed. de F. de P. Samaranch. Buenos Aires: Aguilar Argentina.

Cicerón, Marco Tulio. 1999. Sobre la adivinación, ed. de Ángel Escobar. Madrid: Gredos.

Ciruelo, Pedro. 2005. Reprobación de las supersticiones y hechicerías (1538), ed. facsímil de la de Madrid, 1912. Valladolid: Maxtor.

Cotarelo y Mori, Emilio. 1997. Bibliografía sobre las controversias de la licitud del teatro antiguo español (1904), ed. facsímil con estudio preliminar de L. Suárez García. Universidad de Granada. 
Covarrubias y Horozco, Sebastián de. 1995. Tesoro de la lengua castellana o española, ed. de F.C.R. Maldonado. Madrid: Castalia.

D’Aulnay. 1892. Relación que hizo de su Viaje por España la señora Condesa D'Aulnoy en 1679. Madrid: Tipografía Franco-Española.

Defourneaux, Marcelin. 1973. Inquisición y censura de libros en la España del siglo XVIII. Madrid: Taurus.

Diccionario de la lengua castellana, en que se explica el verdadero sentido de las voces, su naturaleza y calidad..., Madrid: Por los herederos de Francisco del Hierro, 1739, t. VI (contiene las letras s-z).

Diccionario de la lengua española, Real Academia de la Historia, 22a ed., Disponible en http://buscon.rae.es/drae/? type $=3 \&$ val=cultura\&val_aux=\&origen=REDRAE, consultado en 11-01-2016.

Domínguez García, Vicente. 1993. "La ciudad acosada", en Pérez Álvarez, Marino (comp.). La superstición en la ciudad. Madrid: Siglo XxI: 297-308.

Egido, Teófanes. 1988. "Actitudes religiosas de los ilustrados", en Carlos III y la llustración. Madrid: Ministerio de Cultura / Lunwerg.

Egido, Teófanes. 1990. "La religiosidad de los españoles (siglo XVIII)", en Coloquio Internacional "Carlos III y su siglo" (Madrid, 14-17 noviembre 1988). Madrid: Universidad Complutense: t. I, 767-792.

Elorza, Antonio. 1970. La ideología liberal en la Ilustración española. Madrid: Tecnos.

Equipo Madrid. 1988. Carlos III, Madrid y la Ilustración. Madrid: Siglo XXI.

Feijoo y Montenegro, (fray) Benito. 1777. Cartas eruditas, y curiosas. En que, por la mayor parte, se continúa el designio del Theatro Crítico Universal... Madrid: En la Imprenta Real de la Gazeta, 5 volúmenes.

Feijoo y Montenegro, (fray) Benito. 1778. Teatro Crítico Universal, o Discursos varios en todo género de materias, para desengaño de errores comunes (1726-1739). Madrid: Por D. Joachín Ibarra, 8 volúmenes.

Feijoo y Montenegro, (fray) Benito. 1783. Adiciones a las obras del muy llustre, y Reverendísimo Padre Maestro D. F. Benito Gerónimo Feyjoó y Montenegro, Maestro General del Orden de San Benito. Madrid: En la Imprenta de Don Pedro Marín.

Fernández de Moratín, Nicolás y Leandro. 1850. Obras de D. Nicolás y D. Leandro Fernández de Moratín. Madrid: M. Rivadeneira Impresor.

Forner, Juan Pablo. 1787. Discursos filosóficos sobre el hombre, ed. digital basada en la de Madrid, Imprenta Real, disponible en bib.cervantes virtual.com.

Forner, Juan Pablo. 1795. Preservativo contra el ateísmo, ed. digital de la de Sevilla, Félix de la Puerta, disponible en bib.cervantes virtual.com.

Forner, Juan Pablo. 1976. Oración apologética por la España y su mérito literario, ed. digital basada en la ed. de Madrid, Doncel, disponible en bib.cervantes virtual.com.
García Mercadal, José. 1999. Viajes de extranjeros por España y Portugal. Desde los tiempos más remotos hasta comienzos del siglo xx. Salamanca: Junta de Castilla y León.

Goya. Los Caprichos. Dibujos y aguafuertes, 1994. Madrid: Central Hispano.

Gran Enciclopedia Larousse. 1996. Barcelona: Planeta.

Guerrero, Ana Clara. 1990. Viajeros británicos en la España del siglo XVIII. Madrid: Aguilar.

Humboldt, Wilhelm von. 1998. Diario de viaje a España, 1799-1800, ed. de M.A. Vega. Madrid: Cátedra.

Hunter, David E. y Whitten, Philip. 1981. Enciclopedia de Antropología. Barcelona: Ediciones Bellaterra.

Isidoro de Sevilla (San). 1982. Etimologías, ed. de J. Oroz Reta. Madrid: B.A.C.

Jovellanos, Gaspar Melchor de. 1831. Tratado teóricopráctico de enseñanza pública. Madrid: Imprenta de D. León Amarita.

Jovellanos, Gaspar Melchor de. 1858-59. Obras publicadas e inéditas de Don Gaspar Melchor de Jovellanos, ed. de C. Nocedal. Madrid: M. Rivadeneira Impresor, 2 volúmenes.

Jovellanos, Gaspar Melchor de. 1956. Obras, ed. de M. Artola. Madrid: Atlas, B.A.E. t. LXXXV.

Jovellanos, Gaspar Melchor de. 1976. Obras en prosa, ed. de J. Caso González. Madrid: Castalia.

Jovellanos, Gaspar Melchor de. 1998. Espectáculos y diversiones públicas / Informe sobre la Ley Agraria, ed. de G. Carnero. Madrid: Cátedra.

Marchena, José. 1990. Obra española en prosa (Historia, Política, Literatura), ed. de J.F. Fuentes. Madrid: Centro de Estudios Constitucionales.

Menéndez Pelayo, Marcelino. 1987. Historia de los heterodoxos españoles. Madrid: B.A.C., 2 volúmenes.

Moliner, María. 2007. Diccionario de uso del español. Madrid: Gredos.

Moñino y Redondo, José (Conde de Floridablanca). 1867. Obras originales del Conde de Floridablanca y escritos referentes a su persona. Madrid: M. Rivadeneira Impresor.

Pan y toros y otros papeles sediciosos del siglo XVIII. 2010. Madrid: La Piqueta.

Peyron, Jean-François. 1782. Nouveau Voyage en Espagne, fait en 1777 et 1778. Londres: Chez P. Elmsly.

Río, Ma José del. 1988. "Represión y control de fiestas y diversiones en el Madrid de Carlos III", en Equipo Madrid, Carlos III, Madrid y la Ilustración. Madrid: Siglo XXI.

Río, Martín del, 1991. La magia demoníaca, ed. de J. Moya. Madrid: Hiperión.

Robertson, Ian. 1988. Los curiosos impertinentes. Viajeros ingleses por España desde la accesión de Carlos III hasta 1855. Madrid: Serbal / C.S.I.C.

Sánchez, Santos. 1794. Extracto puntual de todas las pragmáticas, cédulas, provisiones, circulares y autos acordados y otras providencias, publicadas en el reynado del señor D. Carlos III. Madrid: En la Imprenta de la Viuda e Hijo de Marín. 
Tomás de Aquino (Santo). Summa Theologica, disponible en http://www.documentacatholicaomnia.eu/03d/ 1225-1274,_Thomas_Aquinas,_Summa_Theologiae,_ ES.pdf, consultado en 11-01-2016.

Townsend, Joseph. 1988. Viaje por España en la época de Carlos III (1786-1787). Madrid: Turner.

Twiss, Richard. 1999. Viaje por España en 1773, ed. de M. Delgado Yoldi. Madrid: Cátedra.

Villars (Marquis de). 1893. Memoires de la Cour d'Espagne de 1679 à 1681, ed. de M.A. Morel-Fatio. París: Librairie Plon.
Villars (Marquise de). 1922. Lettres de la Marquise de Villars. París: Librairie Ollendorff.

Voltaire, François-Marie Arouet. 1819. Dictionnaire Philosophique portatif (Londres, 1764), en Oeuvres complètes de Voltaire, t. VI. París: Chez Antoine-Augustin Renouard.

Voltaire, François-Marie Arouet. 2000. Diccionario filosófico, ed. de A. Martínez Arancón. Madrid: Temas de Hoy.

Voltaire, François-Marie Arouet. 2002. Tratado sobre la tolerancia, ed. de M. Armiño. Madrid: Espasa Calpe. 